\title{
The effects of Roux-en-Y limb length on gastric emptying and enterogastric reflux in rats ${ }^{1}$
}

\author{
Os efeitos do comprimento da alça em Y de Roux sobre o esvaziamento gástrico e o \\ refluxo enterogástrico
}

\author{
Robson Azevedo Dutra I, Wemberton Martins Araújo "I , José Ivan de Andrade ${ }^{\text {III }}$

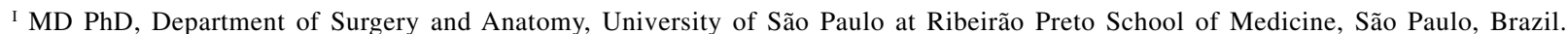 \\ ${ }^{\text {II }}$ MD PhD, Department of Internal Medicine, University of São Paulo at Ribeirão Preto School of Medicine, São Paulo, Brazil

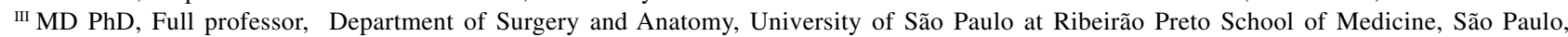 \\ Brazil.
}

\begin{abstract}
Purpose: To assess the effects of Roux-en-Y jejunal limb length on gastric emptying and enterogastric reflux. Methods: Seventy male Wistar rats were submitted to antrectomy with Roux-en-Y reconstruction and then were divided into two groups of 35 animals. Group A, short limb $(7.5 \mathrm{~cm})$ and Group B, standard limb $(15 \mathrm{~cm})$. Group A and B were subdivided into five subgroups each in order to study enterogastric reflux at 30 and 60 minutes and to evaluate gastric emptying at 5,10 and 15 minutes. In order to measure gastric emptying and enterogastric reflux, radiotracers ${ }^{99 \mathrm{~m}}$ Tc-Phytate and ${ }^{99 \mathrm{~m}} \mathrm{Tc}-$ DISIDA were respectively used. Results: For gastric emptying, the radiotracer concentration was lower in Group A than in Group B after five minutes. The enterogastric reflux was present, but there were no significant differences between enterogastric reflux indexes concerning both A and B Groups. Conclusion: A standard Roux limb, besides being unable to protect the stomach from the enterogastric reflux, may become a functional barrier for gastric emptying.
\end{abstract}

Key words: Roux-en-Y. Scintigraphic Methods. Gastric Emptying. Enterogastric Reflux. Roux Stasis Syndrome.

\section{RESUMO}

Objetivo: Determinar os efeitos do comprimento da alça jejunal em Y de Roux sobre o esvaziamento gástrico e o refluxo enterogástrico. Métodos: Setenta e cinco ratos machos foram submetidos à antrectomia com reconstrução em Y de Roux e divididos em dois grupos de 35 animais. Grupo A, alça curta $(7,5 \mathrm{~cm})$ e Grupo B $(15 \mathrm{~cm})$, alça de comprimento padrão. Os grupos A e B foram subdivididos em cinco subgrupos cada para o estudo do refluxo enterogástrico aos 30 e 60 minutos e para o estudo do esvaziamento gástrico aos 5, 10 e 15 minutos. ${ }^{99 \mathrm{~m}}$ Tc-Fitato and ${ }^{99 \mathrm{~m}}$ Tc-DISIDA foram utilizados para os estudos do esvaziamento gástrico e do refluxo enterogástrico, respectivamente. Resultados: No estudo do esvaziamento gástrico, a concentração do radiotraçador foi menor no grupo A do que no Grupo B aos cinco minutos. Foi encontrado o refluxo enterogástrico, nos grupos A e B, sem diferenças entre eles. Conclusão: A alça em Y de Roux de comprimento padrão foi ineficaz em proteger o estômago do refluxo enterogástrico, e pode tornar-se uma barreira funcional ao esvaziamento gástrico.

Descritores: Y de Roux. Métodos Cintilográficos. Esvaziamento Gástrico. Refluxo Enterogástrico. Síndrome da Estase do Y de Roux.

1. Research performed at Gastroenterology Division, Department of Surgery and Anatomy of the Faculty of Medicine of Ribeirão Preto, University of São Paulo (FMRP-USP), Brazil. 


\section{Introduction}

Cesar Roux, surgery professor in Lausanne, Switzerland, in 1897 , described a procedure to alleviate gastric outlet obstruction that consists in a gastrojejunostomy on the posterior stomach wall and a jejunojejunostomy applied $12 \mathrm{~cm}$ distally to the gastrojejunostomy. Many complications as anastomotic ulcers, hemorrhages and perforations, made him abandon the procedure in $1911^{1}$.

In the middle of the twentieth century, many years after Cesar Roux's death, the Y limb was suggested to multiple applications as surgeries in the biliary tract, stomach, liver and pancreas ${ }^{1}$.

After partial gastric resections, the reconstruction of the gastrointestinal transit in Roux-en-Y should prevent the back flow of the biliary, enteric and pancreatic secretions to the gastric stump. However, some complications may occur during a late postoperative period, for example, jejunal ulcers near the gastroenteroanastomosis and, mainly, a delayed gastric emptying that may develop in $30 \%$ of the subjects ${ }^{2}$

Mathias et $\mathrm{al}^{3}$, described the Roux Stasis Syndrome which is characterized by abdominal pain, nausea, and vomiting, worsened after food ingestion. These symptoms may occur due to motor impairment in the Roux-en-Y limb leading to a delayed gastric emptying.

The Roux-en-Y procedure involves an isolated jejunal limb segment that is excluded from the electrical activity generated in the duodenal native pacemaker. This limb does not transmit the distal propagation of the migratory motor complex, and the standard postprandial jejunal motility is either reduced or absent ${ }^{3}$. The emergence of ectopic pacemakers will result in retrograde peristaltic waves $^{4,5}$, thus, delaying gastric emptying being related to a functional obstruction ${ }^{6,7}$.

The Roux-en-Y jejunal limb length that can prevent the enterogastric reflux and promote an appropriate gastric emptying simultaneously has not been defined ${ }^{8}$.

From this view, the aim of this study was to assess the influence of the Roux-en-Y jejunal limb length in rats submitted to a distal gastrectomy (antrectomy), on gastric emptying and enterogastric reflux evaluated by scintigraphic methods.

\section{Methods}

The use of laboratory animals followed the Council for International Organization for Medical Sciences (CIOMS) ethical code concerning animal experimentation. They were supplied by the Central Bioterium of Ribeirão Preto's Medicine School at University of São Paulo. Seventy adult male Wistar rats (weight 250 - $300 \mathrm{~g}$ ) were randomly divided into two groups. In Group A, there were 35 rats submitted to antrectomy and transit reconstruction by using a 7.5centimeter Roux-en-Y (short limb). In Group B, there were 35 antrectomized rats submitted to the same procedure, however, using a 15-centimeter Roux-en-Y (standard limb).

Ninety days after the procedures, the gastric emptying was evaluated at 5,10 and 15 minutes (subgroups
Ae5, Ae10, Ae15 and Be5, Be10, Be15), and the enterogastric reflux was evaluated at 30 and 60 minutes (subgroups Ar30, Ar60, and Br30, Br60).

Sulphuric ether was the anesthetic agent used for the surgical procedures. The gastric emptying was measured by introducing an orogastric catheter and injecting 3.7 MBq of ${ }^{99 \mathrm{~m}}$ Tc-Phytate (Ipen, São Paulo, Brazil) diluted in $20 \mathrm{ml}$ of $9 \%$ sodium chloride. Then, the catheter was removed. Five, ten and fifteen minutes after the administration of the radiotracer (depending on the subgroup), the animals were submitted to a laparotomy. The gastric remnant, the 15 and 7.5 centimeter Roux-en-Y limb, the remaining segments of the small intestine, as well as the colon, were isolated and their ends were tied with 4-0 cotton sutures.

The segments were individually placed into glove fingers, sealed and identified. The amount of gamma-ray emission from each piece was determined (Kilocount/ minute). The sum of the values of each segment was considered $100 \%$, and the radioactivity emitted from the stomach and other intestinal segments were expressed as a percentage of the total.

Intraperitoneal thiopental was the anesthetic agent used to evaluate the enterogastric reflux. The administration of 18.5 MBq of ${ }^{99 m}$ Tc-DISIDA (Ipen, São Paulo) was made intravenously. A laparotomy was performed in order to identify the gastrojejunal anastomosis. Depending on the subgroup to be studied, after 30 and 60 minute, this anastomosis was tied, and $2 \mathrm{ml}$ of $0.9 \%$ sodium chloride solution was injected through an orogastric 6 Fr catheter carefully placed inside the animals' stomachs. Following the gastric content aspiration, the amount of gamma emission was determined. The percentage of radiotracer inside the stomach compared with the total injected intravenously indicated the enterogastric reflux index.

Mann-Whitney test was used for statistical analysis concerning the comparison between the independent samples from Groups A and B. The level of significance was determined $5 \%(\mathrm{p}<0.05)$ for all cases ${ }^{9}$.

\section{Results}

The gastric emptying evaluation demonstrated that the radiotracer concentration in the gastric remnant was lower in Group A than in Group B at 5 minutes (41.69 and 61.98 , respectively), $\mathrm{p}=0.02$. There was no difference between Groups A and B at 10 and 15 minutes (42.65, 39.60 and 37.98, 33.68, respectively) (Figure 1). 


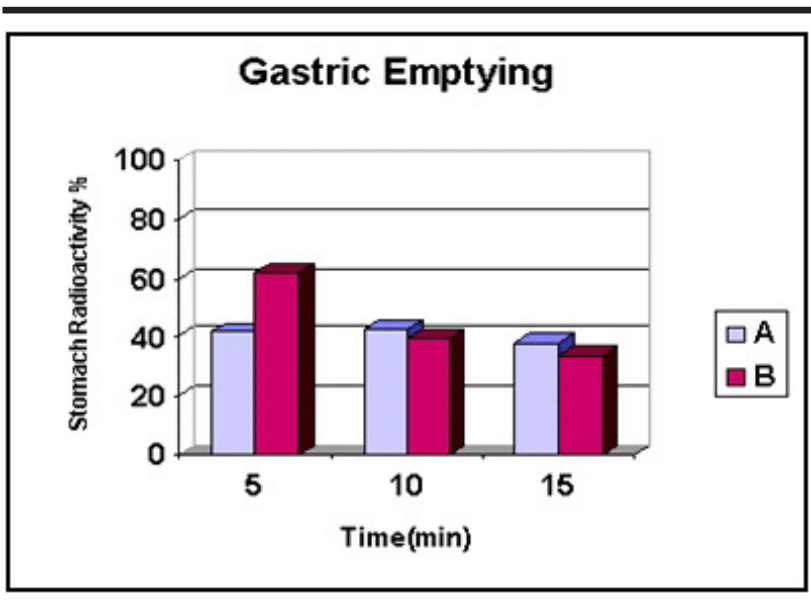

FIGURE 1- Radioactivity emitted by the Stomach at 5, 10 and 15 minutes expressed as a percentage of the total radioactivity emitted by the digestive tract in the groups studied after introduction of Technetium ${ }^{99 m}$ phytate into the stomach through an orogastric catheter.

There was difference concerning the radiotracer concentration in the Roux-en-Y limb between Groups A and $B$ at 5 minutes ( 12.36 and 19.18 , respectively) $p=0.03$. There was no difference in the radiotracer concentration in the Roux-en-Y limb between Groups A and B at 10 and 15 minutes (Figure 2).

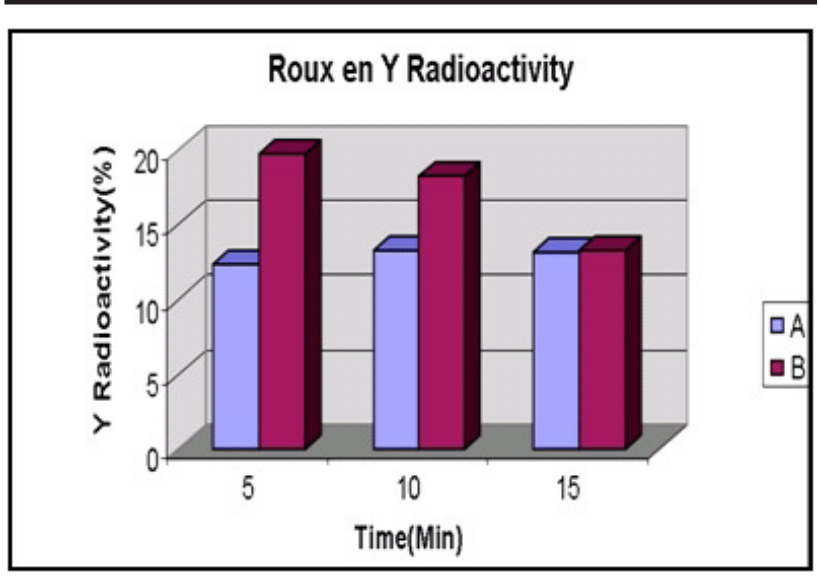

FIGURE 2 - Radioactivity emitted by the Roux limb, at 5, 10 and 15 minutes expressed as a percentage of the total radioactivity emitted by the digestive tract in the groups studied after introduction of Technetium ${ }^{99 \mathrm{~m}}$ phytate into the stomach through an orogastric catheter.

The enterogastric reflux was present and measured at 30 minutes $(0.06$ and 0.06 for Groups $\mathrm{A}$ and B, respectively), $p=0.70$. At 60 minutes $(0.04$ and 0.02 for Groups $\mathrm{A}$ and $\mathrm{B}$, respectively) $\mathrm{p}=0.22$. There was no difference in the enterogastric reflux index when the standard and the short Roux Y limb were compared (Figure 3).

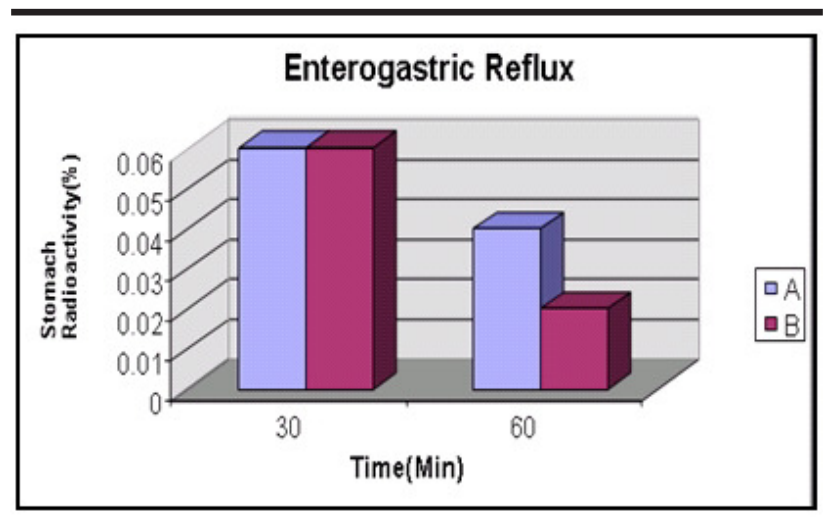

FIGURE 3 - Radioactivity emitted by the Stomach, at 30 and $60 \mathrm{~min}$ after the intravenous injection of Technetium ${ }^{99 m}$ diisopropyl-iminodiacetic acid.

\section{Discussion}

The most suitable Roux-en-Y jejunal limb length, which prevents enterogastric reflux and enable an adequate gastric emptying after distal gastrectomy, is still controversial.

The gastric emptying was evaluated by the radiotracer progression inside rats' digestive tract segments. The enterogastric reflux index was employed by identifying the intravenously injected radiotracer that was taken up by the liver, conducted through the bile ducts to the duodenum and finally refluxed into the stomach.

In humans, the length of the small intestine is approximately $260 \mathrm{~cm}$. The standard $40 \mathrm{~cm}$ employed in the Roux-en-Y procedure is $15 \%$ of this length. Since the length of the small intestine in rats is approximately $100 \mathrm{~cm}^{10}, 15 \%$ and $7.5 \%$ of the total length would correspond to $15 \mathrm{~cm}$ (standard limb) and $7.5 \mathrm{~cm}$ (short limb).

Cesar Roux had proposed in his original description a 12-centimeter limb, while Van Heerden, et al ${ }^{11}$, described good results with a 25-centimeter limb. A study concerning the anti-reflux proprieties of Roux-en-Y limb after gastrectomy concluded that the jejunal limb length would be from 35 to 40 centimeters long. They employed a sequential scintigraphic HIDA Tc ${ }^{99 \mathrm{~m}}$ research that demonstrated the absence of biliary reflux in the stomach remnant ${ }^{12}$. Le Blanc-Louvry et al ${ }^{13}$, reported that it is necessary to compare a short Roux limb that presents only a mild motor impairment, but allows that the enterobiliopancreatic juice flows back into the stomach, to a long Roux limb with significant motor impairment, but protects the stomach from the reflux.

Transection and reanastomosis of the small intestine involve loss of the duodenal native pacemaker control in the Roux-en-Y limb and disturbance of the postprandial contractile pattern ${ }^{14}$. The limb does not transmit the distal propagation of the migratory motor complex and it is influenced by ectopic pacemakers with peristaltic waves of lower and retrograde frequency, thus affecting the complex intestinal motility changing its periodicity, duration, propagation and velocity patterns significantly. Moreover, most patients do not develop the standard postprandial 
contraction pattern ${ }^{14}$. So, the Roux-en-Y limb may be considered a functional barrier. Maintaining myoneural continuity has been proposed to reduce the effects of Roux limb disturbance by using the "Uncut" Roux reconstruction 15,16. Myoelectric activity and motility of the Roux limb after "cut" and "uncut" gastrojejunostomy were evaluated. The authors concluded that the "uncut procedure" may lessen the effects on migrating motor complex, decreasing the impairment of gastrointestinal motility and remarkably increasing the expression of c-kit mRNA related to the presence of interstitial cells of Cajal ${ }^{17}$. In another study, the number of Cajal cells in the region of Auerbach's plexus was higher in "uncut" animals when compared with "cut" Roux limb, and they concluded that this fact was important to the preservation of intestinal motility ${ }^{18}$. The effects of Roux-en-Y or jejunal interposition after total gastrectomy in rats were evaluated concluding that the jejunal interposition induced fewer disturbances on intestinal transit and nutrition status of the rats than those of Roux procedure ${ }^{19}$

A study with 234 adult subjects, submitted to Rouxgastrectomy concluded that patients presenting gastric stasis symptoms had long Roux-en-Y limbs of $41 \mathrm{~cm}$ of average length; moreover, it suggested that the curtailment of such limbs must be done in order to improve the symptoms ${ }^{8}$.

These data demonstrated that gastric emptying was accelerated in Group A than in Group B in five minutes, thus giving support to the thesis that the gastric emptying delay was caused by the standard Roux limb. Such a delay may be explained by the functional barrier in the radiotracer flux caused by the longer length of Roux-en-Y limb in Group B. The higher concentration of ${ }^{99 m}$ Tc-Phytate in the gastric remnant supports such finding.

The gastric emptying of liquid meal in antrectomized rats submitted to Roux-en-Y and Billroth II reconstruction procedures was assessed. A thin silicon catheter was carefully placed inside the Roux-en-Y limb and the Billroth II afferent loop, in order to evaluate the emptying without any interference from the stomach myoeletric events. The transit observed in Roux-en-Y limb was significantly slower than the Billroth II afferent loop, thereby, showing the etiological factor involving Roux-en-Y syndrome ${ }^{6}$. According to our study, the ${ }^{99 m}$ Tc-Phytate higher concentration in the standard Roux-en-Y limb could suggest a delayed transit.

The results obtained by the current study demonstrated that a standard Roux limb induced delayed gastric emptying and could not prevent enterogastric reflux.

\section{Conclusion}

A standard Roux limb, besides being unable to protect the stomach from the enterogastric reflux, may become a functional barrier for gastric emptying.

\section{References}

1. Besson A: The Roux-en-Y loop in modern digestive tract surgery. Am J Surg. 1985; 149:65664.

2. Eagon JC, Miedema BW, Kelly KA. Postgastrectomy Syndromes. Surg Clin North Am. 1992; 72: 445-65.

3. Mathias JR, Fernandez A, Sninsky CA, Clench MH, Davis RH: Nausea, vomiting, and abdominal pain after Roux-en-Y anastomosis: motility of the jejunal limb. Gastroenterology. 1985; 88:101-7.

4. Zobolas B, Sakorafas GH, Kouroukl I I, Glynaatsis M, Peros G, Bramis J: Alkaline reflux gastritis: Early and late results of surgery. World J Surg. 2006; 30(6):1043-9.

5. Karltrom L, Soper NJ, Kelly KA, Phillips SF: Ectopic jejunal pacemakers and enterogastric reflux after Roux gastrectomy: Effect of intestinal pacing. Surgery. 1989; 106: 486-95.

6. Cheng G, Hocking MP, Vogel SB, Snissky CA: The effect of Roux-en-Y diversion on gastric and Rouxlimb emptying in rodent model. Am J Surg. 1995;169:618-21.

7. Houghton AD, Liepins P, Clarke SM, Mason RC: Effect of gastric resection, Roux-en-Y diversion and vagotomy in gastric emptying in the rat. $\mathrm{Br} \mathrm{J}$ Surg. 1994; 106:75-80.

8. Gustavsson S, Ilstrup DM, Morrison P, Kelly KA: Roux-en-Y stasis syndrome after gastrectomy. Am J Surg. 1988;155:490-4.

9. Hollander M, Wolfe DA: Non parametric statistical methods. John Wiley \& Sons. N.Y 1973.

10. Cheng G, Hocking MP, Vogel SB, Sninskt CA. The effect of Roux-en-Y diversion on gastric and Roux limb emptying in rodent model. Am J Surg. 1995;169: 618-21.

11. Van Heerden JA, Priestley JT, Farrow GM, Phillips SF: Postoperative alkaline gastritis. Am J Surg. 1975;11:427-33.

12. Picardi N, Santeusanio E, Tucci G: Study of the anti-reflux function of the Roux-en-Y jejunal loop in reconstruction following gastrectomy. Ann Ital Chir. 2002; 73: 263-6.

13. Le Blanc-Louvry I, Ducrotte P, Lemeland JF, Metayer J, Teniere P: Motility in the Roux-en-Y limb after distal gastrectomy: relation to the length of the limb and afferent duodenojejunal segment an experimental study. Neurogastroenterol Mot. 1999; 11:365-474.

14. Telford DL, Telford SW, Sarna SK: Pathophysiology of small intestinal motility. Surg Clin North Am. 1993;73 (6):1193-9.

15. Van Stiegmann G, Goff JS: An alternative to Rouxen-Y for treatment of bile reflux gastritis. Surg Gynecol Obstet. 1988;166: 69-70.

16. Noh SM: Improvement of the Roux limb function using a new type of "uncut" Roux limb. Am J Surg. 2000;180:37-40. 
17. Zhang,YM, Liu XL, Xue DB, Yun XG: Myoelectric activity and motility of the Roux limb after cut and uncut Roux-en-Y gastrojejunostomy. World J Gastroenterol. 2006;12(47):7699-704.

18. Kiciak A, Wolinski J, Borycka K, Zabielski R, Bielecki K: Roux-en-Y or “un-cut” Roux procedure? Relation of intestinal MMC recovery to the preservation of intersticial cells of the Cajal network in a chronic study on pigs. Exp Physiol. 2006;92(2):399-408.

19. Xin XY, Lei y, Liu FL.Effects of two methods of reconstruction of digestive tract after total gastrectomy on gastrointestinal motility in rats. World J Gastroenterol. 2003; 9(5): 1051-3.

\section{Correspondence:}

Robson Azevedo Dutra

Av. Lázaro de Souza Campos, 990. Bairro São José.

Franca. São Paulo. Brasil.

CEP: 14401295

e-mail address: robsonmarcia@ netsite.com.br

Tel:+55-16-37213184
Conflict of interest: none

Financial source: none

Received: September 10, 2007

Review: November 12, 2007

Accepted: December 12, 2007

\section{How to cite this article}

Dutra RA, Araújo WM, Andrade JI. The effects of Roux-en-Y limb length on gastric emptying and enterogastric reflux in rats. Acta Cir Bras. [serial on the Internet] 2008 Mar-Apr;23(2). Available from URL:

http://www.scielo.br/acb 